\title{
Fire safety in textile industries - A Review
}

\author{
DOI: $10.35530 / I T .070 .06 .1615$
}

\section{ABSTRACT - REZUMAT}

\section{Fire safety in textile industries - A Review}

Over the past decades, textile industries are playing an important role in the Indian economy, and moreover it is the second largest revenue source for the country. The textile industry is the only industry that offers massive employment for both skilled and unskilled labour. Fire accidents cost hundreds of workers' lives and livelihoods along with huge equipment and material loss. The stipulation of proper safety system would be the only option to increase the production rate and quality of the product which in turn amplify the profit and good will of the company. In spite of various initiatives taken to prevent fire accidents in the textile industry, there are still a significant number of fire occurrences in this industry. Fire accident is the major source of accident in case of textile industries, and preventing the fire accident would be the first and foremost choice and also it is mandatory to alleviate the fire accidents to safe guard raw materials and employees. This paper presents a review on various hazards in textile industries. This article intends at studying each of these issues in textile industries, along with the existing possible solutions for these problems. This study is essential in exposing safety concerns in factories around the world.

Keywords: cotton, machinery, risk, combustion, precaution

\section{Siguranța privind incendiile în industria textilă - studiu bibliografic}

În ultimele decenii, industria textilă joacă un rol important în economia indiană și, în plus, este a doua cea mai mare sursă de venit pentru această țară. Industria textilă este singura care oferă locuri de muncă, atât pentru personalul calificat, cât și cel necalificat. Incendiile afectează sute de vieți omenești și traiul muncitorilor, alături de pierderi mari de echipamente și materiale. Stipularea unui sistem de siguranță adecvat ar fi singura opțiune de a crește productivitatea și calitatea produsului care, la rândul său, mărește profitul și bunăstarea companiei. În ciuda diferitelor inițiative luate pentru prevenirea incendiilor în industria textilă, există încă un număr semnificativ de cazuri de apariție în această industrie. Incendiul este principala sursă de accident în industria textilă, iar prevenirea acestuia ar fi prima și cea mai importantă alegere, pentru a asigura paza materiilor prime și a angajaților. Acest studiu prezintă o analiză asupra diverselor pericole din industria textilă. Acest articol are ca scop studiul fiecărei probleme din industria textilă, împreună cu soluțiile posibile existente pentru acestea. Studiul este esențial pentru expunerea problemelor de siguranță în fabricile din întreaga lume.

Cuvinte-cheie: bumbac, utilaje, risc, ardere, prevenție

\section{INTRODUCTION}

In India, textile industries play an important role in the economic life of the country. The GDP generated in India has been fund to boost up the worldwide business to a greater extent as it has brought high revenue. The textile industry contributes 14 percent to the total industrial production in India and hence proved itself as leading sector in Indian earning and it has also claimed to be the biggest revenue earners in terms of foreign exchange among other sectors in India. Despite the economic growth and bright prospects, textile industries are facing challenges in the form of industrial accidents especially fire accidents [1]. Majority of fire accidents occur as a result of carelessness and elimination. The fire is the most unmanageable and the biggest danger to the textile industry [2]. The main causes of fire include static electricity, overheating, human error, atmospheric conditions and machine failures [3]. The workers are not aware of health and safety as they are not properly educated and also the management does not give due importance to promote Occupational Health and Safety in textile industries [4]. The problems can be best avoided by in-depth study and understanding of the manufacturing process and the environment. Hazards in cotton industry are of varying degree right from the inception stage till its finishing process. Understanding the areas of risks in the storage of textile materials and goods as well as the related factors can largely help in the prevention of fire accidents [5]. The textile flammability is generally defined with processes such as burning rates, flame spread rates, characteristics for ignition [6]. The thermal protection of the fabric is influenced by weight, thickness, construction, water vapour, permeability and these properties are related to each other [7]. 


\section{HISTORY AND DEVELOPMENT OF TEXTILE INDUSTRY}

In India, during 400 AD the silk was introduced, while cotton traces back to $3000 \mathrm{BC}$ [8]. The traditional textile industry of India was virtually decayed during the colonial regime. The cotton textile industry, however, made its real beginning in Bombay, in 1850s. The cotton textile industry made rapid progress in the second half of the nineteenth century and by the end of the century there were 178 cotton textile mills. Globalization has had a positive impact on textile exports of India. Countries producing and exporting textiles have increased investment in spinning and weaving equipment [9]. The Indian textile and clothing industry provides a valuable wealth of craftsmanship both skilled and semi-skilled work force which is the major contributor towards the development of apparel units.

\section{LITERATURE REVIEW}

Wan [10] reported on implementing the statutory elements of an occupational safety and health management system model in the working environment of a textile testing laboratory in Hong Kong and suggested that suitability of the established occupational safety and health management system has to be measured and monitored so that improvements could be identified. According to Padmini and Venmathi [11] the causes of fire accidents in Tirupur garment industries include electric short circuit, faulty electrical wiring, smoking materials, boiler explosion, kitchen stove and carelessness. Akhter et al. [12] discussed problem of health and safety issues of female workforce of garment industries in Bangladesh based upon the industry environment, causes of fire accident and their medical facilities.

Nazia Malik et al. [13] studied the role of hazards control measures in Occupational Health and Safety in textile industry using multistage random sampling technique. Wen-hui Ju [14] summarized the fire safety aspects referring to a hundred cotton logistics warehouse fires, based on the relevant provisions of the cotton logistics warehouse. Although in recent years, there have been significant efforts to improve the structural elements of fire safety; there still is a large scope to improve the fire safety in the textile industries [15].

\section{MAJOR SECTORS IN TEXTILE INDUSTRY}

The world's second largest industry is the textile industry next to agriculture, with massive employment for both skilled and unskilled labour. Textile industry includes five major sectors namely ginning, spinning, weaving, dyeing and garment industry [16]. Despite the benefits, workplace safety in this highly labor intensive industry is not satisfactory [17]. Ginning industry is the main sector subject to fire accidents due to reasons like electrical sparks and storing of raw cotton in sun light. Smoking in such areas can cause fire very easily. Textiles that are usually organic may be readily burnt and can actively spread flame. Weaving creates a fair amount of lint, dust and fibre flying which can represent fire hazards if the fibres are combustible [18]. The fire hazards found in a dye works are the flammable solvents used in the processes and certain flammable dyestuffs. The textile industry produces various products out of different natural and artificial fibres. The production of cloth holds many risks of fire. Sparks, glowing embers or overheated particles can be generated along the entire production chain and easily cause fire and dust explosions. Fires that broke out in the storage place of textile materials and textile goods, especially in open storage places, accounts for a relatively large proportion in the fire cases occurred in warehouses.

\section{FIRE HAZARDS IN VARIOUS UNITS OF TEXTILE INDUSTRY}

All the materials that are used in the textile industry are flammable to some extent. The hazards happening in the textile industries are mechanical hazards, physical hazards, chemical hazards, ergonomic hazards and physiological hazards.

In ginning industry, the ginning machine separates cotton fiber in the raw cotton from the cotton seeds for making yarn. Electrical problems in the ginning machine, man made errors, sparks from the machine, and exposure of cotton to sunlight forms the reasons for fire incidents.

In spinning industry, cotton fiber is fabricated in to clothes. Since the raw cotton catches fire easily, the fire hazards in spinning mills are more when compared to the other sectors of textile industry.

When yarn is passed through electrical heating elements in yarn singeing machines to burn out the protruding fibers, electrical spark can be caused. In preparing pigment for printing the fabric, about $70 \%$ of kerosene if used together with other binders. The printed fabric, containing this percentage of kerosene, is then evaporated and fabric is dried. Probabilities of disastrous explosions with resulting fires exist in this process.

Fires due to electrical faults have been more in cotton industry than any other industry. Cotton fluff is easily ignited by a spark by a faulty installation, which could be the cause of a serious fire. Modern machineries are driven by electricity and require power at high pressure. Accumulation of heat in the layer of dust and lint leads to the sudden acceleration of the exothermic oxidation reactions leading eventually to fire spots. These fire spots can migrate through a layer of dust and when they encounter a flammable substance they can trigger fires [19]. 


\section{CAUSES OF FIRE IN TEXTILE INDUSTRY}

Industrial fires and explosions cost companies and governments billions of rupees every year, not to mention the loss of life, which can't be described in monetary terms. The main causes in textile industries include the following.

Combustible Raw Materials: The basic raw material used in textile industries is raw cotton which is itself a combustible material. Cotton is capable of getting ignited even with a small spark and cotton fire spreads very rapidly and causes serious consequences. Other raw materials including bleaching agents, dyes and chemicals can also cause fire.

Sparks: Sparks find their way into dust collector systems from the industrial process. They enter through the hoods and ducts in the collector system.

Type of Building: Nature of construction of a cotton textile industry may pose fire hazards when fire proof class of construction is not made and largely depends on nature of external walls and roof of a building.

Spontaneous combustion: Due to spontaneous combustion of coal in the coal yard and excessive heat in the boiler of the factory, explosion can occur and subsequently break out in the factory. In thermal fluid heaters, oil is heated, circulated, recovered and re-circulated. This process is also susceptible to explosion hazard and subsequent fire.

Electrical Machineries: Faults in electrical circuits can easily ignite the cotton fluff which can cause a serious fire. Heat produced due to the operations of machineries and electrical installation can lead to fire.

\section{PREVENTION OF FIRE ACCIDENTS IN TEXTILE INDUSTRY}

It is the essential to prevent the fire source from warehouses through personnel management and fire protection technology. In case of fire incident, owner, management, government and employees are responsible for controlling the same [20].

The precautionary measures to be adopted at the time of stacking the cotton bales include adequate ventilation and proper stacking of the bales, temperature and humidity control, equipping the warehouse with thermometer and hygrometer to keep the temperature below $308 \mathrm{~K}$ and the humidity below $70 \%$, preventing the possibilities of spontaneous heat and combustion and storing hazardous chemicals away from non-hazardous chemicals. The transportation vehicles, storage vehicles, equipment in warehouses must be installed with flameproof enclosure or choke to ensure no sparks.

The type of building plays an important role in preventing fire in textile industry. Fire risk can be minimized by avoiding materials like wooden partitions, roof linings and false ceilings.

The coal storages are to be kept away from the surrounding and boiler houses must be segregated from the adjacent blocks. Electrical installations must comply with standard requirements and frequent maintenance and inspection of electrical equipments are required. Good housekeeping practices must be observed inside and outside the industry to prevent fire.

Automatic fire alarm systems must be installed to control the spread of the fire or even extinguish fire by automatic sprinkler system.

\section{CONCLUSION}

The article sums up the fire safety issues related to textile industries by analyzing the causes and situations in various sectors of a cotton textile mill leading to fire hazards. The risk of fire pertaining to the materials, type of building, manufacturing processes, machineries and electrical equipments used were discussed. The preventive measures that can be adopted to avoid the incidence of fire were also presented.

\section{REFERENCES}

[1] Mizanuzzaman, M., Loss and Damage Assessment in the Context of Fire Hazards: A Study on Selected Garment Factories in Bangladesh, In: International Journal of Finance and Banking Research, 2016, 2, 2, 24-39

[2] Vasim, K., Avikumar, S., Karbhari, T., The Pioneer Study on Identification of Fire Hazards in Cotton Ginning Industries of Nandurbar Region of Maharashtra, In: International Journal of Scientific Research, 2013, 2, 10, 1-4

[3] Shanmuga, S.P., Raj, Pradeesh T. S., Aravind, Rajand, Jayakrishna, K., A Case Study on Investigation of Fire Accident Analysis in Cotton Mills, 14th international Conference on Humanizing Work and Work Environment, HWWE-2016

[4] Praveen, Kumar, M., Mugundhan, K., Visagavel, K., Occupational Health \& Safety In Textile Industry, In: International Journal of Research in Engineering and Technology, 2014, 3, 11, 168-172

[5] Jian-yun, M., Analysis on the Fire Risk Existing in the Storage of Textile Materials and Textile Goods, In: Procedia Engineering, 2014, 71, 271-275

[6] Gunaydin, K.G., Ceven, E.K., A research on tensile and abrasion properties of fabrics produced from conventional and fire resistant type polyester yarns, In: Industria Textila, 2017, 68, 6, 407-414, https://doi.org/10.35530/ IT.068.06.1484

[7] Muge, D., Ender, Y.B., Yavuz, S., Taner, A., Neural network based thermal protective performance prediction of three-layered fabrics for firefighter clothing, In: Industria Textila, 2019, 70, 1, 57-64, https://doi.org/10.35530/ IT.070.01.1527 
[8] Divya, P., Solanki, A role of textile industry in Indian economy, In: National Journal of Advanced Research, 2017, 3, 3, 60-65

[9] Noopur, T., Eswara, R.E., A Study on Emerging Trends in Textile Industry in India, In: International Journal of Advancements in Research \& Technology, 2013, 2, 7, 267-276

[10] Kan, C.W., Occupational Safety and Health Management System in Textile Industry - A Continual Improvement Approach, RMUTP International Conference: Textiles \& Fashion 2012, July 3-4, 2012, Bangkok Thailand

[11] Padmini, D.S., Venmathi, A., Unsafe Work Environment in Garment Industries, Tirupur, India, In: Journal of Environmental Research and Development, 2012, 7, 1A, 569-575

[12] Akhter, S., Salahuddin, A.F.M., Iqbal, M., Abma, M., Jahan, N., Health and Occupational Safety for Female Workforce of Garment Industries in Bangladesh, In: Journal of Mechanical Engineering, 2010, 41, 1, 65-70

[13] Nazia, M., Ashfaq, A.M., Tariq, S.P., Saira, A., Tanvir A., Role of Hazard Control Measures in Occupational Health and Safety in the Textile Industry of Pakistan, In: Pakistan Journal of Agriculture and Science, 2010, 47, 1, 72-76

[14] Wen-hui, J., Study on Fire Risk and Disaster Reducing Factors of Cotton Logistics Warehouse Based on Event and Fault Tree Analysis, In: Procedia Engineering, 2016, 135, 418-426

[15] Hasan, M., Mahmud, A., Risks Management of Ready-Made Garments Industry in Bangladesh, In: International Research Journal of Business Studies, 2017, 10, 1, 1-13

[16] Karupannan, K.P., Arularasu, M., Devadasan, S.R., Study on Safety Training Programme in Textile Industries, In: International Journal of Control Theory and Applications, 2017, 10, 20, 221-230

[17] Wadud, Z., Huda, F.Y., Fire Safety in the Readymade Garment Sector in Bangladesh: Structural Inadequacy Versus Management Deficiency, In: Fire Technology, 2017, 53, 2, 793-814

[18] Sudha, B., Meenaxi, T., Occupational health hazards in textiles industry, In: Asian Journal of Home Science, 2014, $9,1,267-271$

[19] Olimpiu, S., Dorina, P., Marin, S.N., Alexandru, L.C., Danut, G., Gabriel, T., Catalin, P., Research on the possibilities of reducing the effects of shock waves in case of explosions in environments with dust and textile suspended particulate matter, In: Industria Textila, 2018, 69, 3, 243-248, https://doi.org/10.35530/IT.069.03.1480

[20] Hasan, M.., Mahmud, A., Islam, S., Deadly Incidents in Bangladeshi Apparel Industry and Illustrating the Causes and Effects of These Incidents, In: Journal of Finance and Accounting, 2017, 5, 5, 193-199

\section{Authors:}

PONNUSAMY VENKATARAMANAN ${ }^{1}$, PAULRAJ PRATHAP ${ }^{1}$, PALANISAMY SIVAPRAKASH ${ }^{2}$, KANCHANA SIVAPRAKASH $^{3}$

${ }^{1}$ Anna University, Hindusthan College of Engineering and Technology, Department of Mechanical Engineering, Othakalmandapam via, 641032, Coimbatore, India

e-mail: venkataramananp80@gmail.com; prathu135@gmail.com

${ }^{2}$ Anna University, Dr.N.G.P. Institute of Technology, Department of Mechanical Engineering, 641048, Coimbatore, India

e-mail:drpsivaprakash@gmail.com

${ }^{3}$ Anna University, Sri Ramakrishna Engineering College, Department of Civil Engineering, 641022, Coimbatore, India

e-mail: kash10304@gmail.com

Corresponding author:

PALANISAMY SIVAPRAKASH

e-mail: drpsivaprakash@gmail.com 